\title{
ANALYSIS OF LEGO BRAND COMMUNICATION FOR THE AUDIENCE OF CHILDREN IN SOCIAL MEDIA
}

\section{Diana Volkova1, Jelena Volkova², Daina Znotina ${ }^{3}$}

\author{
${ }^{1}$ Student, Rezekne Academy of Technologies, Rezekne, Latvia, \\ e-mail: dina volkova@inbox.lv \\ ${ }^{2}$ Mg.oec., lecturer, researcher, Rezekne Academy of Technologies, Rezekne, Latvia, \\ e-mail: Jelena.Volkova@rta.lv \\ ${ }^{3}$ Mg.soc.sc., lecturer, researcher, Rezekne Academy of Technologies, Rezekne, Latvia, \\ e-mail: Daina.Znotina@rta.lv
}

Received: 18 September 2020 / Revised: 2 October / Accepted: 20 October 2020 /

Published: 30 November 2020

\begin{abstract}
Social media have become not only a platform for contacts among individuals but also a channel through which companies can maintain constant two-way feedback with consumers. Companies around the world become increasingly aware of the potential of children in the market and increase their communication with the children's audience. The ability to influence a child's choices through communication via social media could give companies an opportunity to increase their sales. The aim of the research is to assess the elements of social media communication for the LEGO brand and their influence on children's audience in Latvia. The research concluded that nowadays it is important for a company to identify the right target audience, and only then, based on the company's strategy, consider the need to use specific tools available in social media. By focusing their communication on children, companies also need to build a parallel relationship with their parents to make sure that the brand is relevant, safe and committed to the values that are relevant to the audience. Nowadays it is fruitful to focus on video content that creates a sense of presence and reality. LEGO is a good source of inspiration for companies in Latvia that want to create a strong brand story, thereby increasing their visibility through communication via social media. The research aim was achieved by identifying the theoretical basis, analysing the communication marketing activities of the LEGO brand focused on children, as well as conducting structured expert interviews and performing a content analysis.
\end{abstract}

Keywords: brand, children's audience, communication, social media. JEL code: $M 31$.

\section{Introduction}

Today social media are a fast-growing platform for communication, information transfer and the formation of worldviews and societal values. Every day, large platforms such as Instagram and Facebook add millions of new user profiles, and the audience of social media users around the world approaches a billion mark.

Companies around the world become increasingly aware of the potential of children in the market and increase their communication with the children's audience. At the same time, children play a number of roles in the 
market as consumers, initiators, influencers and purchase decision-makers, thereby becoming the main consumers of products for many companies. The ability to influence children's choices through communication via social media could give companies an opportunity to increase their sales because the children are able to change their parents' views on the choice of any product. This means that the topic related to the development of marketing communications via social media, specifically for children's audience, will become increasingly important.

The aim of the research is to assess the elements of social media communication for the LEGO brand and their influence on children's audience in Latvia. The research object: social media communication. The research subject: analysis of LEGO brand communication for children's audience in social media.

To achieve the research aim, the following specific research tasks were set:

1. To analyse the interaction of marketing communications and social media.

2. To examine the behaviour of the target audience - children - and the factors affecting it.

3. To perform an analysis of LEGO brand communication in social media.

4. To develop recommendations for the use of marketing elements to reach the audience of children via social media in Latvia.

The research employed the monographic method, which involved a detailed examination of the research object - marketing communication based on the theoretical literature. The interaction of marketing communications and social media was analysed and the elements constituting social media were described by using the monographic method. The monographic method was also used to examine the behaviour of the target audience - children - and the factors affecting it.

In addition, the research employed secondary data analysis to describe the evolution of the LEGO brand and the relevant social media communications as well as content analysis to examine the trends in the number of social media users in Latvia and conducted a structured interview with five marketing industry experts to develop recommendations for the use of marketing elements with the aim of reaching the audience of children via social media in Latvia.

The research used the following information sources: theoretical literature and statistical data, research papers, press releases and other Internet sources pertaining to the marketing and communication industry.

The following hypothesis was put forward: today it is important for a company to identify the right target audience, and only then, based on the 
company's strategy, consider the need to use specific tools available in social media.

\section{Research results and discussion}

At present, marketing communication via social media is considered to be one of the most demanded areas of modern marketing, which allows companies to maintain constant two-way feedback with consumers.

The objectives of marketing communication in the commercial field are as follows: to achieve brand awareness, gain consumer sympathy for the brand, inform the target audience about the goods and services offered and make consumers want to buy the products (Ang, 2014).

Global statistics show that at the beginning of 2020, more than 4.5 billion people used the Internet, while the audience for social media already exceeded 3.8 billion. Almost $60 \%$ of the world's population already used social media, which means that the audience of all social media increased by 9\% in 2020 compared with 2019 (Kemp, 2020).

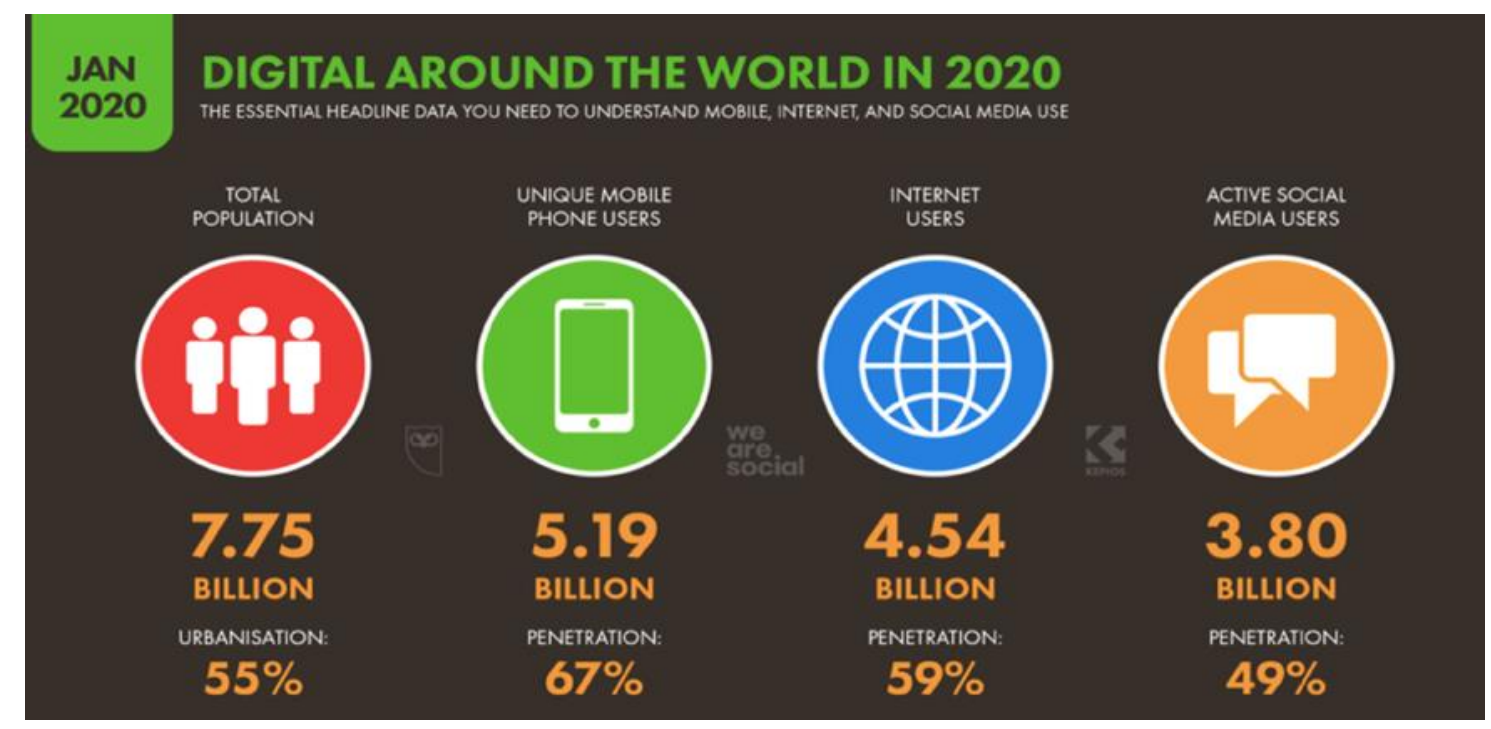

Fig. 1. Number of users of the Internet, digital technologies and social media in the world in 2020 (Kemp, 2020)

The popularity of social media increased across all age groups, reaching the maximum level also among children's audience. Entrepreneurs need to understand more than ever that communication via the Internet needs to focus not only on parents but also on children (Dimitriadis, Tsimonis, 2013). Children is a special group of consumers who look with interest at advertising in social media, like to try innovations and experiment. In addition, children are interested not only in various toys but also in their pocket money, as well as make small purchases independently. 
Particularly popular among foreign researchers P.Thaichon (Thaichon, 2016), A.K.Eranil, T.Dilci (Eranil, Dilci, 2019), M.M.Luo (Luo, 2020) is Uses and gratification theory, which is used to explain the use of social media by children. In fact, this concept is based on an assumption that the use of certain media arises from a desire to meet certain needs. When working with a target audience such as children, the marketer should understand not only the needs and wishes of each child of any age but also how and when they form their own personal opinions (see Figure 2).

Aged 0-3 years.

The child is dependent on the parents

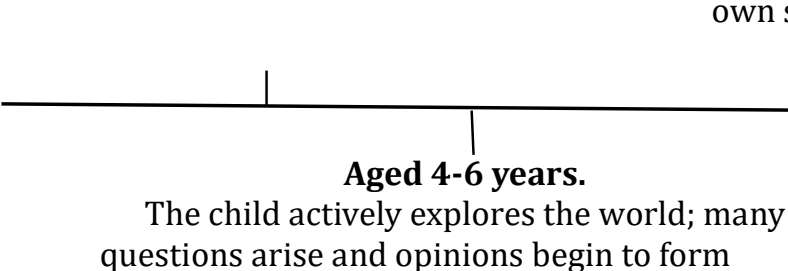

Aged 6-9 years.

The child listens to the parents, yet s/he builds up his/her own social circle
Aged 13-16 years.

The child mostly does not listen to the parents and makes purchases independently

\section{1

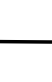

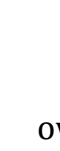

Aged 9-12 years.

The child has his or her own personal opinion and wants to make choices for him/herself

\section{Fig. 2. Differences in specifics of children of various ages}

(Marshall, 2010)

As children's age changes, so does their perceptions. For example, children under the age of 3 are completely dependent on their parents. Preschoolers between the ages of 4 and 6 have and ask a lot of questions. They actively learn the world and ask a lot of questions, as well as begin to shape own personal opinions. Primary school children between the ages of 6 and 9 still listen to their parents, yet they already form their own social circles; this means that the children at this age have an opportunity to receive information from various sources and they take it into account when making a purchase decision. From the age of 9, children have their own opinions, they want to choose a product themselves, and there might be disagreements with their parents. From the age of 13, children very rarely listen to their parents, they begin saving their pocket money and make a purchase decision quite independently. It is also very important to mention that today, owing to the "digital world" available to almost every family, this classic scheme might not work. This means that modern children form their own opinions from childhood, listening not only to their parents but also to people from various social media such as YouTube or Facebook. It has been established that children's loyalty to the brand develops from the age of 5 , which is why one can often hear such an expression as "to grow the target audience". Irrespective of a person's wishes, marketing communications, especially advertising, shape the modern human by influencing parents and especially 
children's vulnerable psyche and triggering the subtle mechanisms of human emotions and motivations (Cohen, 2003). The interests of children of each age should be considered when communicating with the children.

LEGO is one of the world's most valuable brands and toy manufacturers, and the company has also succeeded in social media.

The LEGO brand uses various marketing channels in its communication strategy, including traditional and modern. Traditional marketing channels are associated with tools such as media articles, magazines, in-store advertisements and marketing campaigns. However, much has changed over time in terms of its marketing strategy, and LEGO uses a lot of digital tools to market its brand and products by creating official LEGO platforms in social media.

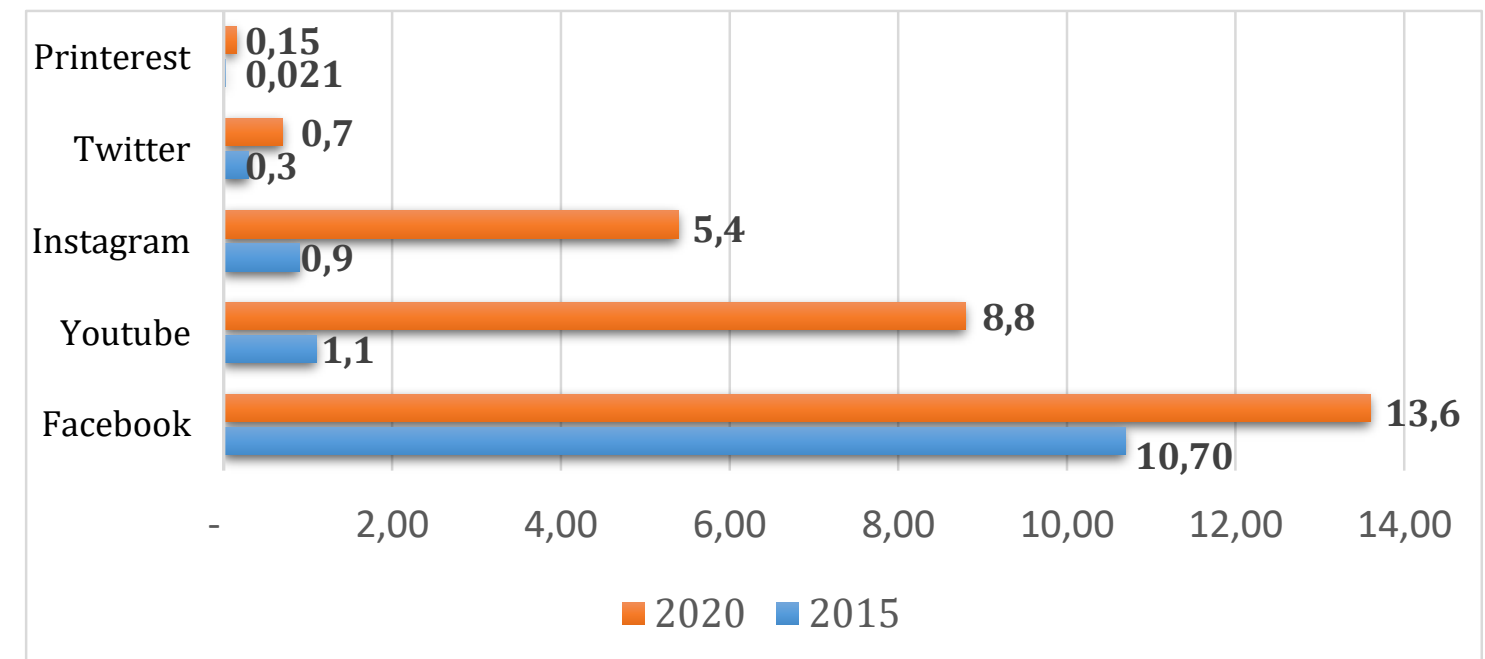

Fig. 3. Number of LEGO brand followers in 2015 and 2020 , $\mathrm{mln}$. (authors' construction)

At present, LEGO uses social networking platforms such as Facebook, Twitter, Instagram, YouTube and Pinterest to communicate with consumers. Promoting new products, LEGO regularly publishes videos on its Instagram and Facebook channels, yet sometimes the videos can include two or more things about its current products. It is also important to note that LEGO reaches an audience of more than 50 million via social media every month, of which about 30 million are reached only through its YouTube channel (The LEGO Group Sustainability Progress, 2019).

The LEGO group not only uses all known platforms for its communication, such as Instagram, Facebook and YouTube, but has also created some platforms in the digital environment where the group provides a link among consumers, for example:

- LEGO encourages consumers to share new building ideas and share their work on a site called LEGO Ideas, where anyone can submit their toy design ideas. 
- In 2017, LEGO decided that children did not have enough opportunities to communicate with their peers and share photos of buildings from a construction game via social media. Therefore, together with the charity organization UNICEF LEGO, a social network LEGO Life for children under 13 years of age was created. By means of the application, which is available on iOS and Android systems, children can communicate with the help of only their emoticons. To date, the project has been implemented in four countries: the United States, the United Kingdom, Germany and France.

To further promote the new series, LEGO uses its YouTube channel, where opinion influencers show the new product in an interesting way, tell about it, as well as highlight its advantages. Over the past five years, LEGO has developed a social networking strategy that has significantly enhanced its brand awareness and, consequently, sales (Thita, 2020). This strategy is based on content that connects the company with consumers, as evidenced by the fact that consumer feedback is highly visible on LEGO social networking platforms. LEGO's followers actively comment on its articles and share their experiences through feedback.

The most popular and oldest LEGO platform in social media in terms of number of followers is Facebook, which almost 3 million followers have joined in a period of five years. LEGO has been virtually communicating with consumers on the YouTube platform since 2014, yet since 2015 the brand has managed to increase the number of followers by 7.7 million. In 2020, the Instagram LEGO profile involved 5.4 million followers, which was 4.5 million more than in 2015. The number of followers has also increased on platforms such as Twitter and Pinterest. It is important to add that each platform has its specifics, which are also adapted to the age and interests of the followers. As it was established earlier in the present research, the LEGO brand carefully adapts its communication via social media to the specifics of children's age (Table 1).

\section{Table 1. LEGO brand communication solutions via social media according to the specifics of children (authors' own compilation)}

\begin{tabular}{|l|l|}
\hline Specifics of children & \multicolumn{1}{c|}{ LEGO solution } \\
\hline $\begin{array}{l}\text { Specifics of children's world } \\
\text { view }\end{array}$ & $\begin{array}{l}\text { Creates an opportunity to explore and discover the } \\
\text { world based on brand communication }\end{array}$ \\
\hline $\begin{array}{l}\text { Spontaneous change of } \\
\text { interests }\end{array}$ & $\begin{array}{l}\text { Uses various platforms where the content is adapted } \\
\text { to each construction game theme individually }\end{array}$ \\
\hline Influence on parents & $\begin{array}{l}\text { Parents are a parallel audience, for which content on } \\
\text { Facebook and Twitter is customized }\end{array}$ \\
\hline
\end{tabular}




\begin{tabular}{|l|l|}
\hline Desire to get everything ready & $\begin{array}{l}\text { Communication shows that it is much more fruitful to } \\
\text { develop creative abilities and create your own } \\
\text { individual construction game }\end{array}$ \\
\hline Reluctance to wait & $\begin{array}{l}\text { Daily articles. New series are released on the YouTube } \\
\text { platform every week }\end{array}$ \\
\hline Pursuit of wealth and power & $\begin{array}{l}\text { Uses your imagination not only during the game but } \\
\text { also in the YouTube series }\end{array}$ \\
\hline Desire for a fun time & $\begin{array}{l}\text { Entire brand communication is based on having fun, } \\
\text { combined with creativity and a positive attitude } \\
\text { towards life }\end{array}$ \\
\hline $\begin{array}{l}\text { Several individual } \\
\text { psychological traits }\end{array}$ & $\begin{array}{l}\text { Tries to discover each child's potential abilities and } \\
\text { talents by creating content in which the child wants to } \\
\text { get involved and share his/her experiences }\end{array}$ \\
\hline $\begin{array}{l}\text { Desire to be part of a reference } \\
\text { group }\end{array}$ & \begin{tabular}{l} 
Uses opinion leaders in its communication \\
\hline Fears
\end{tabular} \\
$\begin{array}{l}\text { Promotes the desire to create a favourable mutual } \\
\text { communication, to express one's fears through } \\
\text { communication }\end{array}$ \\
\hline
\end{tabular}

By adapting its content posted in social media to the specifics of children, LEGO tries to meet one or some of the children's emotional needs that they cannot meet in their real lives. The target audience of the LEGO brand is mainly children aged from 1 to 15 years, while the brand has a lot of customers and followers also among adults. LEGO offers not only special products for customers segmented according to age but also segments its consumers in social networks and offers customized content.

Table 2. Analysis of social media content for the LEGO brand (authors' own compilation

\begin{tabular}{|c|c|c|c|}
\hline Platform & Content & $\begin{array}{c}\text { Publication } \\
\text { frequency }\end{array}$ & Specifics \\
\hline You 1 & $\begin{array}{l}\text { New product } \\
\text { presentations, } \\
\text { short films, } \\
\text { reviews; } \\
\text { Live broadcasts. } \\
\end{array}$ & $\begin{array}{l}\text { Once a } \\
\text { week }\end{array}$ & $\begin{array}{l}\text { The content is adapted to each } \\
\text { construction game theme. } \\
\text { The new construction game is presented } \\
\text { by opinion leaders. }\end{array}$ \\
\hline & $\begin{array}{l}\text { Contests, games, } \\
\text { news, short films, } \\
\text { questionnaires. }\end{array}$ & $\begin{array}{c}\text { 1-2 articles } \\
\text { a day }\end{array}$ & $\begin{array}{l}\text { The content is designed to involve more } \\
\text { followers in various competitions and } \\
\text { games. } \\
\text { Followers can share their experiences } \\
\text { on the Facebook platform. }\end{array}$ \\
\hline & $\begin{array}{l}\text { Contests, short } \\
\text { films, games, } \\
\text { direct advertising. }\end{array}$ & $\begin{array}{c}\text { 1-2 articles } \\
\text { a day }\end{array}$ & $\begin{array}{l}\text { The content includes direct advertising } \\
\text { of the latest series of construction games } \\
\text { and their descriptions. }\end{array}$ \\
\hline
\end{tabular}




\begin{tabular}{|c|l|l|l|}
\hline & $\begin{array}{l}\text { Contests, short } \\
\text { films, } \\
\text { discussions. }\end{array}$ & $\begin{array}{l}\text { Contests based on feedback from } \\
\text { a day } \\
\text { consumers with photos. } \\
\text { Quick response to followers' } \\
\text { questions/feedback/comments. } \\
\text { The content includes short films about } \\
\text { the products. }\end{array}$ \\
\hline antertainment \\
$\begin{array}{l}\text { articles, ideas } \\
\text { (life hacks). }\end{array}$ & $\begin{array}{l}\text { 1-2 articles } \\
\text { a day }\end{array}$ & $\begin{array}{l}\text { The content is adapted to each } \\
\text { construction game theme individually. } \\
\text { Followers share construction game } \\
\text { ideas with each other. }\end{array}$ \\
\hline
\end{tabular}

An individual approach is applied to each platform (Table 2).

1. YouTube. Short films represent an important part of LEGO's marketing strategy. The brand uses YouTube to publish all kinds of videos, including educational ones, which are aimed at increasing its brand awareness, increasing sales and increasing the number of followers. On the YouTube platform, LEGO presents new construction game series through opinion leaders. LEGO follows all the trends of events, for example, uses cartoon characters in their products. The company has licensing agreements with The Simpsons, Harry Potter, Star Wars and other cartoons. This allows the company to place short films on its YouTube platform, which demonstrate both the brand's products and the characters from the world's most popular cartoons.

2. Facebook. LEGO has over 13 million followers on Facebook. It has reached a great level of user engagement on Facebook. The brand publishes 1-2 articles every day, and most of them receive thousands of "likes". On the Facebook platform, LEGO offers its followers to participate in contests, games, as well as surveys. Questionnaires help the brand to find out consumers' opinions about a new product, as well as its followers have an opportunity to offer improvements or suggestions for the development of a new LEGO series.

3. Instagram is also one of the leading marketing channels used by LEGO. Its content is similar to that on Facebook. The LEGO Instagram platform has more than 5 million followers. The LEGO brand publishes images and videos on Instagram, as well as advertises the latest design series and their descriptions.

4. On the Twitter platform, LEGO offers its followers to participate in contests based on feedback from consumers with photos. Quick answers to followers' questions, feedback and comments are available on the Twitter platform on the LEGO part. There are often discussions on various topical issues, which also pertain to LEGO construction games.

5. Pinterest is the smallest platform used by LEGO. On the Pinterest platform, followers have an opportunity to share photos with each other. The 
content is adapted to each theme of the construction game individually, and the followers can choose the most interesting things and post an article.

The increase in the number of followers shows that the brand carefully adapts the content posted in social media to its target audience, which is designed for young children, young people and adults. Based on the authors' previous analyses, the experts were asked to answer questions pertaining to corporate communication via social media and communication aimed at children's audience, as well as to assess LEGO brand communication.

Today children have very close familiarity with all current trends and developments; therefore, companies need to be able to deal with content for children and their vocabulary and interests. Children know all technological news, and entertainment is important to them; therefore, the companies that want to address their communication to children should understand all the current issues relevant to the children. An important factor that needs to be adapted to communication with children's audience is an appropriate design of the content - bright and noticeable. The research concluded that currently any company can successfully address the children's audience via YouTube, Instagram and TikTok while communicating with parents via Facebook and Instagram.

The research found out that communicating with children's audience via social media, companies should also know the specifics of children and their main wishes. Promoting a product could lead to a loss of consumer confidence, which is why LEGO builds relationships with consumers by engaging them in social networking. The research also found that LEGO is a good source of inspiration for companies in Latvia that want to create a strong brand story, thereby increasing their visibility through communication via social media.

\section{Conclusions and suggestions}

Analysing the LEGO brand communication with children's audience via social media as well as performing an in-depth examination of the marketing industry expert opinions, the authors have developed recommendations to Latvian companies that provide a better idea of communication aimed at the target audience of children. To reach the target audience of children, Latvian's companies need to:

1. Give consumers what they wish. Today it is important for a company in the market not only to supply a quality product but also promote loyalty by communicating with consumers via social media, especially if the company focuses on marketing children's products. The company should focus on what gives the most satisfaction to the target audience 
chosen. It is necessary to follow up on what consumers actually feel and want to expect.

2. Encourage active followers. Addressing a company's communication with children's audience via social media, it is important to ensure the children are involved in it. This means that the company should take care not only to arose interest in the children but also a desire to get involved in the company's communication and share positive feedback. For example, the company should offer its followers to participate in contests based on feedback from consumers with photos. By encouraging its active followers, the company promotes loyalty to its brand and products.

3. Use popular films, books and TV shows in a company's communication. Successful marketing campaigns often use popular TV cartoon characters to help address the audience and engage it the company's communication. They attract more children's attention and arose interest in the children. However, it is important for each company to find its own individual approach to communication with consumers, researching in advance the right target audience, its interests and everyday problems, and then address it accordingly.

4. Following the trends, create a cult of the company's product. The authors mentioned above that the company should carefully follow all relevant trends, be able to deal with content for children and their vocabulary and interests in order to arose interest in the children.

5. An appropriate communication channel via social media. It is important to note that for a company to communicate effectively, it should be definitely done via the right channel. Different generations do not want to be in the same social media space, i.e. together with their parents or children. It also means that companies have to adapt to individuals' habits in their communication and carefully follow the data on how their customers use the media. The authors concluded that currently the children's audience could be successfully addressed via YouTube, Instagram and TikTok while communicating with parents via Facebook and Instagram.

6. The right audience and customized content. The authors concluded that a company should primarily identify the right target audience and only then adapt its communication delivered via social media. The content aimed at children should be understandable, while messages should be short, diverse and entertaining. This means the company needs to communicate in child-friendly and easy-to-use language, not in adult language. Game elements should be involved in the communication as much as possible so that the child is interested in acting and there are some quick and easy assignments to complete. 
7. The graphic design of communication should be visible. Visual design in communication with children via social media is an important factor. Children are aware of all current events and trends; therefore, it is necessary to follow the trends in graphic design in order to remain competitive. A well-thought out design allows the company to stand out and be noticeable.

8. The company has to be able to think beyond traditional boundaries. Addressing its communication with children's audience via social media, the company should constantly consider various nontraditional, new approaches and opportunities to reach the children and involve them in its communication. In case the company is not experienced in communicating with children, it is recommended to test its communication content or ideas on a small group of children before posting them in social media.

\section{References}

1. Ang, L. (2014). Principles of Integrated Marketing Communication. Cambridge University Press.

2. Cohen, B. (2003). Getting the Word Out: Marketing Children's Books. Washington, p.287.

3. Dimitriadis, S., Tsimonis, G. (2013). Brand Strategies in Social Media. Department of Marketing and Communication, Athens University of Economics and Business.

4. Eranil A.K, Dilci T. (2019) The Impact of Social Media on Children. Handbook of Research on Children's Consumption of Digital Media. IGI Global.

5. Kemp, S. (2020). Digital 2020: Global Digital Overview. Retrieved July 18, 2020 from https://datareportal.com/reports/digital-2020-global-digital-overview

6. Luo, M.M. (2020). Uses and gratifications theory and digital media use: the test of emotional factors. International Journal of Social Sciences, 6(1), p.599-608.

7. Marshall, D. (2010). Understanding Children as Consumers, Los Angeles: Sage, p.211.

8. Thaichon, P. (2017). Consumer socialization process: The role of age in children's online shopping behavior. Journal of Retailing and Consumer Services, 4, p.38-47.

9. The LEGO Group Sustainability Progress 2019. (2019). Retrieved July 28, 2020 from https://www.lego.com/en-us/aboutus/lego-group/policies-andreporting/reports/

10. Thita. (2020). LEGO 2019 Annual Report \& Financial Results. Retrieved July 9, 2020 from http://thebrickblogger.com/2020/03/lego-2019-annual-reportfinancial-results/ 